\title{
The Mosquito Larvicidal Activity of Essential Oils from Cymbopogon and Eucalyptus Species in Vietnam
}

\author{
Ho Dung Manh ${ }^{1}{ }^{*} \mathbb{D}$, Do Thi Hue ${ }^{1}$, Nguyen Thi Thanh Hieu ${ }^{1}$, Doan Thi Thanh Tuyen ${ }^{1}$ and \\ Ong Thi Tuyet ${ }^{2}$ \\ 1 Department of Pharmaceutical Chemistry, Faculty of Pharmacy, Lac Hong University, Bien Hoa, \\ Dong Nai 810000, Vietnam; dohue1103@gmail.com (D.T.H.); hieunguyen.4496@gmail.com (N.T.T.H.); \\ tuyendoan312@gmail.com (D.T.T.T.) \\ 2 Department of Physiology, Faculty of Pharmacy, Lac Hong University, Bien Hoa, Dong Nai 810000, Vietnam; \\ tuyetong2610@gmail.com \\ * Correspondence: manhho@lhu.edu.vn
}

Received: 2 January 2020; Accepted: 14 February 2020; Published: 17 February 2020

check for updates

\begin{abstract}
The larvicidal activity of essential oils (EOs) extracted from Cymbopogon citratus, Cymbopogon winterianus, Eucalyptus citriodora, and Eucalyptus camaldulensis aromatic plants grown in Vietnam was evaluated on Aedes aegypti larvae. The EOs were hydro-distilled in a Clevenger-type apparatus. The EOs were analyzed by gas chromatography-mass spectrometry (GC-MS). The mortality rates obtained from the bioassays were used to calculate the lethal concentrations $\left(\mathrm{LC}_{50}\right)$ of the EOs by the probit analysis method. These essential oils exhibited toxicity to the larvae of Aedes aegypti. Results were obtained for Cymbopogon citratus $\left(\mathrm{LC}_{50}=120.6 \mathrm{ppm}\right)$, Cymbopogon winterianus $\left(\mathrm{LC}_{50}=38.8 \mathrm{ppm}\right)$, Eucalyptus citriodora $\left(\mathrm{LC}_{50}=104.4 \mathrm{ppm}\right)$, and Eucalyptus camaldulensis $\left(\mathrm{LC}_{50}=33.7 \mathrm{ppm}\right)$. The essential oils of Eucalyptus camaldulensis and Cymbopogon winterianus were found to be the most efficient, and their respective values of $\mathrm{LC}_{50}$ were $33.7 \mathrm{ppm}, 38.8 \mathrm{ppm}$. In conclusion, this research adds to the growing body of literature on natural larvicides from essential oils against Aedes aegypti mosquitoes.
\end{abstract}

Keywords: essential oils; Cymbopogon species; Eucalyptus species; larvicide; Aedes aegypti; Vietnam

\section{Introduction}

Dengue is the most important vector-borne infectious disease in the world. It is estimated that more than 50 million infections occur and half a million individuals are hospitalized due to dengue hemorrhagic fever each year. The infection is caused by one of four dengue virus serotypes: DENV-1, DENV-2, DENV-3, or DENV-4. [1,2] The Aedes mosquito is the primary vector for the transmission of dengue fever. A successful integrated mosquito control strategy includes several tactics, such as removing mosquito breeding sites and using synthetic chemical insecticides (pyrethroids, organophosphates, etc.) to control the spread of adult or larval forms of Aedes aegypti [3].

While synthetic chemicals have successfully controlled Aedes mosquito populations, the tremendous increase in their use has led to insecticide resistance in mosquito vectors [4] and adverse effects on non-target organisms, including humans [5].

Therefore, developing safe and eco-friendly insecticides is important for public health. In this direction, plant essential oils (EOs) have been shown to be potential alternatives to synthetic insecticides against mosquito vectors [6,7]. Plant-based insecticides are considered environmentally safe and have no or little effects on non-target organisms, in addition to being locally available in many parts of the world affected by mosquito-borne diseases [8-10]. Furthermore, EOs containing mixtures of active components act on insects at different target sites or with different modes of action and thus might reduce resistance in mosquito populations [11]. 
In the present study, we aim to extract four EOs from Cymbopogon citratus, Cymbopogon winterianus, Eucalyptus citriodora, and Eucalyptus camaldulensis aromatic plants grown in Vietnam and to determine the larvicidal activity of these EOs against Aedes aegypti mosquitoes.

\section{Materials and Methods}

\subsection{Essential Oil Extraction}

Cymbopogon citratus, Cymbopogon winterianus, Eucalyptus citriodora, and Eucalyptus camaldulensis leaves were collected in several locations in Vietnam in July 2018 (Table 1). Voucher specimens (1801, 1802, 1901, and 1902, respectively) have been deposited in the Centre of Research and Applied Technology, Lac Hong University, Vietnam.

Table 1. Location of the collected plants, registration number (voucher), and yield of essential oil.

\begin{tabular}{lccc}
\hline Scientific Name & Location & Voucher No. & Yield\% (V/W) \\
\hline Cymbopogon citratus & District 9, Ho Chi Minh & 1801 & 0.33 \\
Cymbopogon winterianus & Dau Tieng, Binh Duong & 1901 & 1.30 \\
Eucalyptus citriodora & Moc Hoa, Long An & 1802 & 2.10 \\
Eucalyptus camaldulensis & Bien Hoa, Dong Nai & 1902 & 0.61 \\
\hline
\end{tabular}

Fresh plant leaves $(500 \mathrm{~g})$ were submitted to hydrodistillation for $2 \mathrm{~h}$ using a modified Clevenger-type apparatus. The essential oils were collected, dried with anhydrous sodium sulfate, and stored in airtight containers before analysis by GC-MS. The yields were determined based on the fresh weight of the leaf plant materials.

\subsection{Determination of Major Constituents}

The analysis of all essential oils was performed using a gas chromatography-mass spectrometry (GC-MS) system consisting of an Agilent 6890N gas chromatograph coupled to a 5973 mass spectrometer. The chromatographic separation was achieved on an HP-5MS capillary column $(30 \mathrm{~m} \times 0.25 \mathrm{~mm}$ i.d. $\times$ $0.25 \mu \mathrm{m}$ film thickness). The initial column temperature of $50{ }^{\circ} \mathrm{C}$ was held for $2 \mathrm{~min}$ and increased by 2 ${ }^{\circ} \mathrm{C} / \mathrm{min}$ to $80{ }^{\circ} \mathrm{C}$; then the temperature was raised to $150{ }^{\circ} \mathrm{C}$ at $5^{\circ} \mathrm{C} / \mathrm{min}$, increased to $200{ }^{\circ} \mathrm{C}$ at $10^{\circ} \mathrm{C} /$ $\mathrm{min}$, and increased to $300^{\circ} \mathrm{C}$ at $20^{\circ} \mathrm{C} / \mathrm{min}$. The temperature was then held there for $5 \mathrm{~min}$. Helium was used as the carrier gas at a flow rate of $1 \mathrm{~mL} / \mathrm{min}$. The injector temperature was maintained at 250 ${ }^{\circ} \mathrm{C}$. The diluted samples (1:40 v/v in n-hexane) were injected at $1 \mu \mathrm{L}$ in splitless mode. Each component was identified by using its relative retention index alongside the Wiley registry of mass spectral library and NIST MS Search. The percentage composition was calculated by integrating the peak areas of the spectrograms.

\subsection{Mosquito Larvae}

The colony of Aedes aegypti used in this study was reared in the Department of Parasitology, Faculty of Pharmacy, Lac Hong University. Adults were maintained in cages $(30 \mathrm{~cm} \times 20 \mathrm{~cm} \times 20$ $\mathrm{cm}$ ) at a temperature of $27 \pm 3{ }^{\circ} \mathrm{C}$, with $70 \% \pm 5 \%$ relative humidity under a 16:8 h light/dark cycle. Mosquitoes were maintained on a $10 \%$ sucrose solution with the blood of live mice, whereas larvae were reared in plastic trays and fed with Wiskcat food (for cats). The larvae between the third and fourth stages of Aedes aegypti served as the test organisms.

\subsection{Larvicidal Assay}

The larvicidal bioassay was carried out according to the recommendations of WHO [12]. The essential oils were serially diluted in ethanol to obtain the stock solutions in different concentrations. Twenty-five 3rd or 4th instar larvae were introduced into cups containing $100 \mathrm{~mL}$ of distilled water. Damaged or unhealthy larvae were replaced. For each concentration, we performed tests three times. 
Control tests were performed simultaneously with $1 \mathrm{~mL}$ of alcohol in distilled water. The test containers were kept at $25-28^{\circ} \mathrm{C}$ with a photoperiod of a $12: 12 \mathrm{~h}$ light/dark cycle. Larval mortality was recorded after $24 \mathrm{~h}$ exposure.

\subsection{Data analysis}

The 24-h mortality and test concentration data were subjected to probit analysis using the SPSS (IBM, version 22.0, Armonk, NY, USA) software program. The probit-log(concentration) regression model was used to calculate $\mathrm{LC}_{50}$ values, $95 \%$ fiducial limits, slopes, standard errors (SE), chi-square $\left(x^{2}\right)$ value, and degrees of freedom.

\section{Results and Discussion}

\subsection{Yield of Essential Oils}

Table 1 shows the yields of the EOs obtained by a simple hydrodistillation of Cymbopogon citratus, Cymbopogon winterianus, Eucalyptus citriodora, and Eucalyptus camaldulensis leaves. The highest oil yield was $2.10 \%$, obtained from Eucalyptus citriodora, while the lowest oil yield was $0.33 \%$, obtained from Cymbopogon citratus (Table 1).

\subsection{Chemical Composition of Essential Oils}

Table 2 shows the major constituents of the EOs. Four constituents, which accounted for $97.4 \%$ of the Cymbopogon citratus essential oil, were geranial (49.3\%), neral (36.2\%), $\beta$-myrcene $(7.8 \%)$, and geraniol $(4.1 \%)$. The high percentage of citral $(85.5 \%)$, which is a mixture of the two geometric isomers geranial and neral, is in good agreement with previous studies [13-15]. While Cymbopogon citratus is known for its high content of citral, Cymbopogon winterianus is known to possess an oil rich in some monoterpenoids, such as citronellal, citronellol, geraniol, and elemol [16-18]. In this study, the essential oil of Cymbopogon winterianus, also known as citronella oil, mainly consists of elemol (29.5\%), citronellal $(23.5 \%)$, citronellol (7.5\%), and geraniol (6.1\%). Citronella oil is well known for its natural mosquito repellent properties and is of great interest in the pharmaceutical, perfumery, and cosmetic industries.

Table 2. Chemical constituents of essential oils.

\begin{tabular}{|c|c|c|c|c|}
\hline \multirow[b]{2}{*}{ Constituents } & \multicolumn{4}{|c|}{$\%$ of Oil } \\
\hline & $\begin{array}{c}\text { Cymbopogon } \\
\text { citratus }\end{array}$ & $\begin{array}{l}\text { Cymbopogon } \\
\text { winterianus }\end{array}$ & $\begin{array}{c}\text { Eucalyptus } \\
\text { citriodora }\end{array}$ & $\begin{array}{c}\text { Eucalyptus } \\
\text { camaldulensis }\end{array}$ \\
\hline 1,8-Cineol & & & & 42.6 \\
\hline Neral & 36.2 & & & \\
\hline Citronellal & & 23.5 & 78.6 & \\
\hline Citronellyl acetate & & 2.9 & 1.7 & 5.6 \\
\hline Elemol & & 29.5 & & \\
\hline Germacrene D & & 2.8 & & \\
\hline Germacrene D-4-ol & & 4.7 & & \\
\hline Isomenthone & & & & \\
\hline Isopulegol & & & 7.2 & \\
\hline Geranial & 49.3 & & & \\
\hline Geraniol & 4.1 & 6.1 & & \\
\hline$\alpha$-Pinene & & & & 32.1 \\
\hline$\alpha$-Terpineol & & & & 1.8 \\
\hline Citronellol & & 7.5 & 12.1 & \\
\hline$\beta$-Elemene & & 4.4 & & \\
\hline$\beta$-Myrcene & 7.8 & & & \\
\hline$\beta$-Pinene & & & & 4.4 \\
\hline
\end{tabular}


Eucalyptus, a member of the family Myrtaceae, is a popular cultivated plant in Vietnam. Among the Eucalyptus species, the EO extracted from Eucalyptus citriodora usually contains a high content of citronellal. In this study, the major constituents of Eucalyptus citriodora oil were citronellal $(78.6 \%)$, citronellol (12.1\%), and isopulegol (7.2\%). Plants cultivated in Brazil [19], Argentina [20], and the Democratic Republic of the Congo [21] also produce EOs with a high content of citronellal. While Eucalyptus citriodora is known for its high content of citronellal, Eucalyptus camaldulensis is known to possess an oil rich in 1,8-cineole. In this study, the major constituents of Eucalyptus camaldulensis oil were 1,8-cineol (42.6\%), $\alpha$-pinene (32.1\%), and citronellyl acetate (5.6\%). Eucalyptus camaldulensis oils with a high content of 1,8-cineole were also reported in the Democratic Republic of the Congo [21], Egypt [22], and Tunisia. [23]

\subsection{Mosquito Larvicidal Activity of Essential Oil}

Table 3 shows the mosquito larvicidal activity for Cymbopogon citratus, Cymbopogon winterianus, Eucalyptus citriodora, and Eucalyptus camaldulensis leaf essential oils. Cymbopogon citratus was the least effective EO since it has the highest value of $\mathrm{LC}_{50}$. This result is comparable with the results of earlier findings. Sosan et al. [24] and Vera et al. [7] reported that Cymbopogon citratus had an $\mathrm{LC}_{50}$ of nearly $120 \mathrm{ppm}$ and $123 \mathrm{ppm}$, compared to $120.6 \mathrm{ppm}$ in the present study. In comparison with Cymbopogon citratus, Cymbopogon winterianus essential oil has a lower $\mathrm{LC}_{50}$ value of $38.8 \mathrm{ppm}$. Mendonca et al. [25] investigated an ethanol extract of Cymbopogon winterianus leaves against Aedes aegypti larvae and found a higher $\mathrm{LC}_{50}$ value of $98 \mathrm{ppm}$. This result indicates that Cymbopogon winterianus essential oil was more effective against Aedes aegypti larvae than its ethanol extract.

Table 3. Larvicidal activity of each essential oil (EO) evaluated in larvae of Aedes aegypti at $24 \mathrm{~h}$.

\begin{tabular}{lcccccc}
\hline Essential Oils & $\boldsymbol{n}$ & Slope $( \pm \mathbf{S E})$ & $\mathbf{L C}_{\mathbf{5 0}} \mathbf{( \mathbf { p p m } ) \mathbf { ( 9 5 } \% \mathbf { F L } )}$ & $\boldsymbol{\chi}^{\mathbf{2}}$ & $\mathbf{d f}$ \\
\hline Cymbopogon citratus & 475 & $5.33 \pm 0.44$ & 120.6 & $(111.6-130)$ & 25.1 & 17 \\
Cymbopogon winterianus & 300 & $3.57 \pm 0.48$ & 38.8 & $(31.5-45.6)$ & 20.4 & 10 \\
Eucalyptus citriodora & 375 & $5.39 \pm 0.53$ & 104.4 & $(98.1-111.4)$ & 12.0 & 13 \\
Eucalyptus camaldulensis & 300 & $6.53 \pm 0.64$ & 33.7 & $(30.1-36.9)$ & 15.3 & 10 \\
\hline
\end{tabular}

$n$ : represents the number of larvae tested.

In this study, the $\mathrm{LC}_{50}$ value of Eucalyptus citriodora essential oil was $104.4 \mathrm{ppm}$. This result is slightly higher compared to the previous findings of Vera et al. [7], where the EO extracted from Eucalyptus citriodora grown in Colombia had an $\mathrm{LC}_{50}$ value of $70 \mathrm{ppm}$. In comparison with Eucalyptus citriodora, Eucalyptus camaldulensis essential oil had a much lower $\mathrm{LC}_{50}$ value (33.7 ppm). This low $\mathrm{LC}_{50}$ value was in good agreement with previous reports in which Eucalyptus camaldulensis essential oil was able to induce $50 \%$ mortality at a concentration of around $30.0 \mu \mathrm{g} / \mathrm{mL}$. [26,27]. In comparison with Bti $\left(\mathrm{LC}_{50}=0.026 \mathrm{ppm}\right)[28]$ and Neem oil formulations $\left(\mathrm{LC}_{50}=1.7 \mathrm{ppm}\right)$ [29], the $\mathrm{LC}_{50}$ of the four essential oils were much higher. Although these EOs show promising activity, the low efficacy of these EOs compared to commercial products has limited their application in practice.

Regarding the mode of action, several mechanisms through which essential oils produce neurotoxic effects have been proposed, such as EOs acting on GABA receptors, octopamine receptors, or acetylcholinesterase [30]. Further, the synergistic effect of the essential oil constituents likely increases their larvicidal activity [31-33]. Scalerandi et al. proposed an interesting mode for synergistic effects using the metabolic model [34]. They have shown that while the major component in the mixture is targeted by the detoxification system of the insect, the minor component intoxicates the insect. As a result, the minor component will be more toxic than when it was assayed alone since the detoxification system of the insect fights the main component. 


\section{Conclusions}

Our findings suggest that all the EOs exhibit toxicity to the larvae of Aedes aegypti, especially the essential oils of Eucalyptus camaldulensis and Cympobogon winterianus leaves, which may be potentially suitable for controlling mosquitoes at the larval stage. However, field evaluations and further research on the EOs' potential toxicology for non-target organisms is necessary.

Author Contributions: Conceptualization, H.D.M.; methodology, H.D.M.; software, D.T.H.; validation, O.T.T. and H.D.M.; formal analysis, D.T.H.; investigation, N.T.T.H. and D.T.T.T.; resources, H.D.M.; data curation, D.T.T.T.; writing—original draft preparation, O.T.T.; writing—review and editing, H.D.M.; visualization, N.T.T.H.; supervision, H.D.M.; project administration, H.D.M.; funding acquisition, O.T.T. All authors have read and agreed to the published version of the manuscript.

Funding: This research was funded by Lac Hong University, grant number LHU-RF-MP-18-01-12.

Acknowledgments: The authors are very much grateful to Nguyen Thi Thanh Thuy, Institute of Applied Materials Science at Ho Chi Minh city for their valuable help in GC-MS analysis of the essential oils. Again, authors are thankful to Bui My Linh for provide plants authenticated by a plant taxonomist from the Department of Botany, Ho Chi Minh University of Medicine and Pharmacy.

Conflicts of Interest: The authors declare no conflict of interest.

\section{References}

1. Simmons, C.P.; Farrar, J.J.; van Vinh Chau, N.; Wills, B. Dengue. N. Engl. J. Med. 2012, 366, $1423-1432$. [CrossRef] [PubMed]

2. Guzman, M.G.; Halstead, S.B.; Artsob, H.; Buchy, P.; Farrar, J.; Gubler, D.J.; Hunsperger, E.; Kroeger, A.; Margolis, H.S.; Martí-nez, E.; et al. Dengue: A Continuing Global Threat. Nat. Rev. Microbiol. 2010, 8, S7-S16. [CrossRef] [PubMed]

3. Benelli, G. Research in Mosquito Control: Current Challenges for a Brighter Future. Parasitol. Res. 2015, 114, 2801-2805. [CrossRef] [PubMed]

4. Smith, L.B.; Kasai, S.; Scott, J.G. Pyrethroid Resistance in Aedes aegypti and Aedes albopictus: Important Mosquito Vectors of Human Diseases. Pestic. Biochem. Physiol. 2016, 133, 1-12. [CrossRef]

5. Koureas, M.; Tsakalof, A.; Tsatsakis, A.; Hadjichristodoulou, C. Systematic Review of Biomonitoring Studies to Determine the Association between Exposure to Organophosphorus and Pyrethroid Insecticides and Human Health Outcomes. Toxicol. Lett. 2012, 210, 155-168. [CrossRef]

6. Pavela, R. Essential Oils for the Development of Eco-Friendly Mosquito Larvicides: A Review. Ind. Crops Prod. 2015, 76, 174-187. [CrossRef]

7. Vera, S.S.; Zambrano, D.F.; Méndez-Sanchez, S.C.; Rodríguez-Sanabria, F.; Stashenko, E.E.; Duque Luna, J.E. Essential Oils with Insecticidal Activity against Larvae of Aedes aegypti (Diptera: Culicidae). Parasitol. Res. 2014, 113, 2647-2654. [CrossRef]

8. Govindarajan, M.; Rajeswary, M.; Benelli, G. Chemical Composition, Toxicity and Non-Target Effects of Pinus kesiya Essential Oil: An Eco-Friendly and Novel Larvicide against Malaria, Dengue and Lymphatic Filariasis Mosquito Vectors. Ecotoxicol. Environ. Saf. 2016, 129, 85-90. [CrossRef]

9. Pavela, R. Insecticidal Properties of Pimpinella anisum Essential Oils against the Culex quinquefasciatus and the Non-Target Organism Daphnia magna. J. Asia. Pac. Entomol. 2014, 17, 287-293. [CrossRef]

10. Stroh, J.; Wan, M.T.; Isman, M.B.; Moul, D.J. Evaluation of the Acute Toxicity to Juvenile Pacific Coho Salmon and Rainbow Trout of Some Plant Essential Oils, a Formulated Product, and the Carrier. Bull. Environ. Contam. Toxicol. 1998, 60, 923-930. [CrossRef]

11. Feng, R.; Isman, M.B. Selection for Resistance to Azadirachtin in the Green Peach Aphid, Myzus persicae. Experientia 1995, 51, 831-833. [CrossRef]

12. World Health Organization. Guidelines for Laboratory and Field Testing of Mosquito Larvicides; World Health Organization: Geneva, Switzerland, 2005; pp. 1-41. Available online: https://apps.who.int/iris/handle/10665/ 69101 (accessed on 12 May 2018).

13. Bassolé, I.H.N.; Lamien-Meda, A.; Bayala, B.; Obame, L.C.; Ilboudo, A.J.; Franz, C.; Novak, J.; Nebié, R.C.; Dicko, M.H. Chemical Composition and Antimicrobial Activity of Cymbopogon citratus and Cymbopogon giganteus Essential Oils Alone and in Combination. Phytomedicine 2011, 18, 1070-1074. [CrossRef] 
14. Saleem, M.; Afza, N.; Anwar, M.A.; Hai, S.M.A.; Ali, M.S.; Shujaat, S. Atta-Ur-Rahman. Chemistry and Biological Significance of Essential Oils of Cymbopogon citratus from Pakistan. Nat. Prod. Res. 2003, 17, 159-163. [CrossRef]

15. Santin, M.R.; Dos Santos, A.O.; Nakamura, C.V.; Dias Filho, B.P.; Ferreira, I.C.P.; Ueda-Nakamura, T. In Vitro Activity of the Essential Oil of Cymbopogon Citratus and Its Major Component (Citral) on Leishmania amazonensis. Parasitol. Res. 2009, 105, 1489-1496. [CrossRef]

16. Lal, R.K.; Sharma, J.R.; Misra, H.O.; Sharma, S.; Naqvi, A.A. Genetic Variability and Relationship in Quantitative and Qualitative Traits of Java Citronella (Cymbopogon winterianus, Jowitt). J. Essent. Oil Res. 2001, 13, 158-162. [CrossRef]

17. Kakaraparthi, P.S.; Srinivas, K.V.N.S.; Kumar, J.K.; Kumar, A.N.; Rajput, D.K.; Sarma, V.U.M. Variation in the Essential Oil Content and Composition of Citronella (Cymbopogon winterianus Jowitt.) in Relation to Time of Harvest and Weather Conditions. Ind. Crops Prod. 2014, 61, 240-248. [CrossRef]

18. Rodrigues, K.A.D.F.; Dias, C.N.; Do Amaral, F.M.M.; Moraes, D.F.C.; Mouchrek Filho, V.E.; Andrade, E.H.A.; Maia, J.G.S. Molluscicidal and Larvicidal Activities and Essential Oil Composition of Cymbopogon winterianus. Pharm. Biol. 2013, 51, 1293-1297. [CrossRef]

19. Maciel, M.V.; Morais, S.M.; Bevilaqua, C.M.L.; Silva, R.A.; Barros, R.S.; Sousa, R.N.; Sousa, L.C.; Brito, E.S.; Souza-Neto, M.A. Chemical Composition of Eucalyptus Spp. Essential Oils and Their Insecticidal Effects on Lutzomyia longipalpis. Vet. Parasitol. 2010, 167, 1-7. [CrossRef]

20. Toloza, A.C.; Zygadlo, J.; Cueto, G.M.; Biurrun, F.; Zerba, E.; Picollo, M.I. Fumigant and Repellent Properties of Essential Oils and Component Compounds Against Permethrin-Resistant Pediculus Humanus capitis (Anoplura: Pediculidae) from Argentina. J. Med. Entomol. 2006, 43, 889-895. [CrossRef]

21. Cimanga, K.; Apers, S.; De Bruyne, T.; Van Miert, S.; Hermans, N.; Totté, J.; Pieters, L.; Vlietinck, A.J.; Kambu, K.; Tona, L. Chemical Composition and Antifungal Activity of Essential Oils of Some Aromatic Medicinal Plants Growing in the Democratic Republic of Congo. J. Essent. Oil Res. 2002, 14, 382-387. [CrossRef]

22. Salem, M.Z.M.; Zidan, Y.E.; Mansour, M.M.A.; El Hadidi, N.M.N.; Abo Elgat, W.A.A. Antifungal Activities of Two Essential Oils Used in the Treatment of Three Commercial Woods Deteriorated by Five Common Mold Fungi. Int. Biodeterior. Biodegrad. 2016, 106, 88-96. [CrossRef]

23. Ben Jemâa, J.M.; Haouel, S.; Bouaziz, M.; Khouja, M.L. Seasonal Variations in Chemical Composition and Fumigant Activity of Five Eucalyptus Essential Oils against Three Moth Pests of Stored Dates in Tunisia. J. Stored Prod. Res. 2012, 48, 61-67. [CrossRef]

24. Sosan, M.; Adewoyin, F.; Adewunmi, C. Larvicidal Properties of Three Indigenous Plant Oils on the Mosquito Aedes aegypti. Niger. J. Nat. Prod. Med. 2001, 5. [CrossRef]

25. De Mendonça, F.A.C.; Da Silva, K.F.S.; Dos Santos, K.K.; Ribeiro Júnior, K.A.L.; Sant'Ana, A.E.G. Activities of Some Brazilian Plants against Larvae of the Mosquito Aedes aegypti. Fitoterapia 2005, 76, 629-636. [CrossRef]

26. Cheng, S.S.; Huang, C.G.; Chen, Y.J.; Yu, J.J.; Chen, W.J.; Chang, S.T. Chemical Compositions and Larvicidal Activities of Leaf Essential Oils from Two Eucalyptus Species. Bioresour. Technol. 2009, 100, 452-456. [CrossRef]

27. Lucia, A.; Licastro, S.; Zerba, E.; Masuh, H. Yield, Chemical Composition, and Bioactivity of Essential Oils from 12 Species of Eucalyptus on Aedes aegypti Larvae. Entomol. Exp. Appl. 2008, 129, 107-114. [CrossRef]

28. Fansiri, T.; Thavara, U.; Tawatsin, A.; Krasaesub, S.; Sithiprasasna, R. Laboratory and Semi-Field Evaluation of Mosquito Dunks ${ }^{\circledR}$ against Aedes aegypti and Aedes albopictus Larvae (Diptera: Culicidae). Southeast Asian J. Trop. Med. Public Health 2006, 37, 62-66.

29. Dua, V.K.; Pandey, A.C.; Raghavendra, K.; Gupta, A.; Sharma, T.; Dash, A.P. Larvicidal Activity of Neem Oil (Azadirachta indica) Formulation against Mosquitoes. Malar. J. 2009, 8, 2-7. [CrossRef]

30. Rattan, R.S. Mechanism of Action of Insecticidal Secondary Metabolites of Plant Origin. Crop. Prot. 2010, 29, 913-920. [CrossRef]

31. Dhinakaran, S.R.; Mathew, N.; Munusamy, S. Synergistic Terpene Combinations as Larvicides against the Dengue Vector Aedes aegypti Linn. Drug Dev. Res. 2019, 80, 791-799. [CrossRef]

32. Osanloo, M.; Sedaghat, M.M.; Esmaeili, F.; Amani, A. Larvicidal Activity of Essential Oil of Syzygium aromaticum (Clove) in Comparison with Its Major Constituent, Eugenol, against Anopheles stephensi. J. Arthropod. Borne. Dis. 2018, 12, 361-369. [CrossRef] [PubMed] 
33. Hummelbrunner, L.A.; Isman, M.B. Acute, Sublethal, Antifeedant, and Synergistic Effects of Monoterpenoid Essential Oil Compounds on the Tobacco Cutworm, Spodoptera litura (Lep., Noctuidae). J. Agric. Food Chem. 2001, 49, 715-720. [CrossRef] [PubMed]

34. Scalerandi, E.; Flores, G.A.; Palacio, M.; Defagó, M.T.; Carpinella, M.C.; Valladares, G.; Bertoni, A.; Palacios, S.M. Understanding Synergistic Toxicity of Terpenes as Insecticides: Contribution of Metabolic Detoxification in Musca domestica. Front. Plant Sci. 2018, 871, 1-9. [CrossRef] [PubMed] 